\title{
The optimal amino acid supplementation of barley for the growing pig
}

\section{Response of nitrogen metabolism to progressive supplementation}

\author{
By M. F. FULLER, R. M. LIVINGSTONE, BARBARA A. BAIRD \\ AND T. ATKINSON \\ Rowett Research Institute, Bucksburn, Aberdeen AB2 $9 S B$
}

(Received 3 April 1978 - Accepted 20 July 1978)

I. In five experiments, involving 142 female pigs weighing on average $33 \mathrm{~kg}$, estimates were made of the amounts of essential amino acids which minimized urinary $\mathrm{N}$ excretion when diets with barley as the only source of protein were given at the rate of $120 \mathrm{~g} / \mathrm{kg}^{0.75}$ per d.

2. With additions of lysine $(4.0 \mathrm{~g} / \mathrm{kg}$ diet $)$ and threonine $(\mathrm{I} \cdot 2 \mathrm{~g} / \mathrm{kg}$ diet $)$ to barley urinary $\mathrm{N}$ excretion decreased from 0.91 to $0.36 \mathrm{~g} / \mathrm{kg}^{0.75}$ per $\mathrm{d}$, corresponding to an increase in biological value (BV) from 0.51 to 0.86 .

3. With these additions of lysine and threonine, there were no responses to additions of tryptophan, methionine or isoleucine, or to further additions of lysine or threonine, but addition of histidine significantly reduced $\mathrm{N}$ excretion.

4. No optimal addition of histidine could be determined; the mean rate of $\mathrm{N}$ excretion after addition of histidine (not less than $0.3 \mathrm{~g} / \mathrm{kg}$ diet) was $0.27 \mathrm{~g} / \mathrm{kg}^{0.75}$ per d, corresponding to a BV of 0.93 .

5. There was a variation between pigs from different litters in their responses to added histidine. Those with low rates of $\mathrm{N}$ excretion on the unsupplemented diet did not respond to additions of histidine, but those with high rates did.

6. It is concluded that additions of only three amino acids can greatly improve the nutritive value of barley protein for the growing pig and that the amino acid composition of the supplemented protein closely approaches the ideal; it is also similar to whole-body tissue protein.

Barley is the staple of diets for pigs in Britain. As well as providing most of the dietary energy, barley typically contributes half or more of the protein in a pig diet. As a protein to support the growth of the pig, however, its quality is poor. In common with other cereals barley is seriously deficient in lysine, and to a lesser extent in other amino acids. The addition of other proteins to barley in the formulation of diets for pigs therefore has the dual objective of increasing the dietary protein and of correcting the imbalances of the barley protein. How well this last objective can be achieved depends in part on how precisely known are the amino acid requirements of the pig.

It is now established that threonine is the second-limiting amino acid in barley for the growing pig (Chung \& Beames, 1974; Fuller et al. 1974, 1975; Aw-Yong \& Beames, 1975). In a second paper (Fuller et al. 1979) we describe the improvements in the growth of pigs kept under practical conditions which can be achieved by additions of lysine and threonine to barley. The present paper describes the studies made to determine the additions of amino acids required to minimize the nitrogen excretion of pigs given barley as the only source of protein.

The principles to be followed in the amino acid supplementation of foods were set out clearly by Rosenberg (1959) and by Rosenberg \& Eckert (I96I). According to these principles, the first-limiting amino acid is added until it and the second-limiting amino acid are equally limiting; these two are then increased together in proportion to the requirements of the animal until they and the third-limiting amino acid are equally limiting, and so on. This procedure, whilst undoubtedly correct, relies on precise previous knowledge of the animal's amino acid requirements. In the instance of the growing pig these are still surrounded by

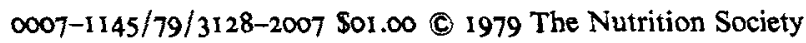


considerable doubt. The Agricultural Research Council (I967) estimated the requirements of the growing pig ( 8 weeks to $50 \mathrm{~kg}$ ) for only five essential amino acids; even for some of these the information available was sparse and discordant. The (US) National Research Council (I973) presented estimates of requirements for all essential amino acids, but did not review the evidence on which these were based. Rérat \& Lougnon (I 968) reviewed the experimental evidence on requirements for lysine, threonine, methionine + cystine, tryptophan and isoleucine, together with more speculative estimates made of requirements for the remaining essential amino acids by other authors. Many of these values were based on the estimation of the amounts of an amino acid in a diet which gave satisfactory performance; such information is not of the most critical kind.

To avoid any a priori assumptions about the animal's requirements, we have made an alternative approach in which the optimal amino acid supplementation of barley protein is estimated by a series of successive approximations. The first experiment on this principle was reported briefly (Fuller et al. 1974). In that experiment, a minimum urinary $\mathrm{N}$ excretion was obtained when L-lysine was added to barley at the rate of $3.6 \mathrm{~g} / \mathrm{kg}$. This quantity of lysine was then added to the basal diet. Further additions of lysine, or of methionine, isoleucine or tryptophan were without effect, but addition of threonine reduced $\mathrm{N}$ excretion substantially, demonstrating it to be the second-limiting amino acid. This paper describes a continuation of that study but, to avoid the possibility of confounding amino acid requirements with the size of the animal, it is confined to a series of pigs of a single weight, $33 \mathrm{~kg}$.

\section{EXPERIMENTAL}

Although this work was done with eleven groups of pigs over a period of more than 2 years, it consists basically of five experiments. These are described in Table $I$.

\section{Animals}

Female pigs weighing initially $25-30 \mathrm{~kg}$ were selected from the Rowett Research Institute's herd. They were the progeny of Large White boars and Large White $\times$ Landrace sows. Their mean weights during the balance trials are shown in Table I.

\section{Diets and feeding}

The composition of the basal diet used in all experiments is given in Table 2. The animals were given this diet at the rate of $120 \mathrm{~g} / \mathrm{kg}^{0.76}$ per $\mathrm{d}$ in two equal meals with $2.0 \mathrm{l}$ water with each. No other water was given. The amount of food was maintained constant during each 2-week period and was based on the weight of the animal at the beginning of the experiment, increased by $3 \mathrm{~kg}$ to allow for the probable weight gain to the mid-point of the experiment. In Expt 3 the ration was adjusted in this way at the start of each lo d period.

\section{Analytical methods}

Two batches of barley were used, the first in Expts $1-3$, the second in Expts 4 and 5, and in the experiment reported in the second paper (Fuller et al. 1979). Twelve portions of each batch were hydrolysed in $6 \mathrm{M}$-hydrochloric acid under reflux, six for $24 \mathrm{~h}$ and six for $48 \mathrm{~h}$. Four samples were treated with performic acid to oxidize methionine and cystine. Tryptophan was determined by Matheson's (1973) method. The results are shown in Table 3 . Comparison of the $24 \mathrm{~h}$ and $48 \mathrm{~h}$ hydrolysates showed a decrease in threonine and increases in other amino acids; the latter were substantial only in the instances of leucine and isoleucine. It is assumed that these differences reflect losses during hydrolysis in the former instance and increasing completeness of hydrolysis in the latter. Accordingly, the preferred estimate for threonine is that made by extrapolation to zero time of values obtained after 


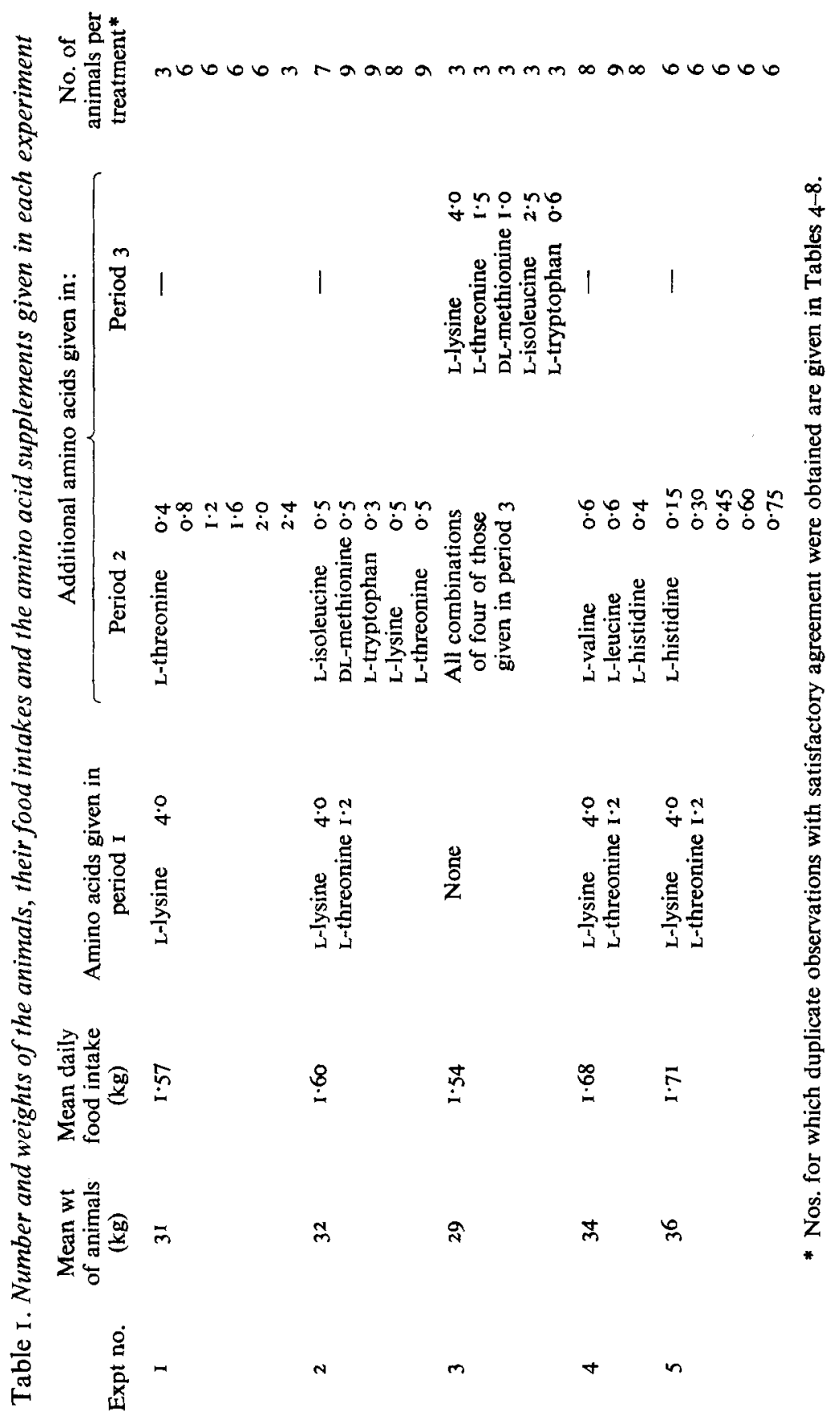


Table 2. Composition ( $\mathrm{kg} /$ tonne) of basal diet used in all experiments

$\begin{array}{lc} & \mathrm{kg} / \text { tonne } \\ \text { Ground barley } & 970 \\ \text { Ground limestone } & 15.8 \\ \text { Dicalcium phosphate } & 4.4 \\ \text { Common salt (sodium chloride) } & 3.1 \\ \text { Vitamin and mineral supplement } & 2.5\end{array}$

* Supplying (/tonne diet): retinol $300 \mathrm{mg}$, cholecalciferol $25 \mathrm{mg}$, riboflavin $2 \mathrm{~g}$, DL-calcium pantothenate $10 \mathrm{~g}$, nicotinic acid $10 \mathrm{~g}$, cyanocobalamin $9 \mathrm{mg}$, menaphthone $5 \mathrm{~g}$, copper $200 \mathrm{~g}$, zinc $100 \mathrm{~g}$, manganese $3 \circ \mathrm{g}$, iron $60 \mathrm{~g}$, cobalt $0.9 \mathrm{~g}$, iodine $\mathrm{I} \mathrm{g}$.

Table 3. Composition of the barley samples

$\begin{array}{lcc}\text { Sample ... } & \text { A } & \text { B } \\ \text { Expt no. ... } & 1-3 & 4 \text { and } 5 \\ \text { DM } & 0.88 & 0.84 \\ \text { Protein (nitrogen } \times 6.25) & 0.116 & 0.095 \\ \text { Amino acids (g/kg protein) } & & \\ \quad \text { Threonine } & 29.9 & 30 \cdot 0 \\ \text { Valine } & 41 \cdot 3 & 48 \cdot 0 \\ \text { Isoleucine } & 29.4 & 33.8 \\ \text { Leucine } & 58.5 & 63.4 \\ \text { Tyrosine } & 23.2 & 33.3 \\ \text { Phenylalanine } & 42.0 & 41 \cdot 4 \\ \text { Histidine } & 17.4 & 19.7 \\ \text { Lysine } & 35.8 & 35.2 \\ \text { Methionine } & 17.7 & 17.5 \\ \text { Cystine } & 24.6 & 23.4 \\ \text { Tryptophan } & 9.6 & 9.8\end{array}$

DM, dry matter.

$24 \mathrm{~h}$ and $48 \mathrm{~h}$ hydrolysis. For other amino acids the preferred estimates are those obtained after $48 \mathrm{~h}$ hydrolysis.

Urea concentrations were estimated by the method of Marsh et al. (I965), modified for use with an AutoAnalyzer (Technicon Instruments Corp., Tarrytown, New York, USA). $\mathrm{N}$ was estimated by the Kjeldahl method.

\section{Procedures}

The animals were fed individually for $7-10 \mathrm{~d}$ in pens and were then put into metabolism cages and introduced to the experimental diets. After they had been habituated to the cages for $7 \mathrm{~d}$, Foley catheters (I 4 gauge; Warne Surgical Products, Andover, Hants) were introduced into the bladder. With most animals the vagina was large enough to admit a finger, with which the urethral meatus could be located and which guided the lubricated tip of the catheter into the urethra. With smaller pigs it was necessary to introduce the catheter visually, using a speculum and a stylet to stiffen the catheter. For this the animals were lightly anaesthetized with trichloroethylene (Trilene; ICI Ltd, Macclesfield, Cheshire) and supported in a sling with a hole for each leg. Catheters, which had a nominal balloon capacity of $5-15 \mathrm{ml}$, were inflated with $7 \mathrm{ml}$ water. Antiseptic precautions were observed throughout; first, by cleaning the exterior area of the animal and the operator's hands in a solution of Cetrimide (Savlon; ICI Ltd, Macclesfield, Cheshire), secondly, by the use of antiseptic lubricant (Lubrel; Willington Medicals Ltd, Shrewbury, Shropshire) and thirdly, by the administration of antibiotic (Tribrissen; The Wellcome Foundation, London) for $3 \mathrm{~d}$ after the catheters were introduced. 


\section{Measurements}

Each experiment (except Expt 3) consisted of two periods of $7 \mathrm{~d}$; urine was collected for two successive periods of $48 \mathrm{~h}$ at the end of each $7 \mathrm{~d}$ period (i.e. days $4-5,6-7$, I I-I 2 and $13-\mathrm{I}_{4}$ ). Results for any animal were discarded if the successive measurements of $\mathrm{N}$ excretion in each part of the experiment failed to give reasonable agreement. In Expt $\mathrm{I}$, this meant within $0.1 \mathrm{~g} / \mathrm{kg}^{0.75}$ per $\mathrm{d}$; in subsequent experiments, when rates of $\mathrm{N}$ excretion were less, 0.07 $\mathrm{g} / \mathrm{kg}^{0.75}$ per $\mathrm{d}$, corresponding to $6 \%$ of the mean excretion on the unsupplemented diet. In Expt 3 the criterion of response was the excretion of urea, rather than of $N$. The amino acid supplements given in each period are shown in Table $\mathrm{I}$.

\section{RESULTS AND DISCUSSION}

\section{Expt I}

This experiment measured the response of urinary $\mathrm{N}$ excretion to graded additions of $\mathrm{L}$-threonine to the basal diet with L-lysine $(4.0 \mathrm{~g} / \mathrm{kg})$ added. The additional lysine above the optimum of $3.6 \mathrm{~g} / \mathrm{kg}$ estimated previously was intended to allow for any improvements in BV which subsequent additions of amino acids might give. The results are given in Table 4. Urinary $\mathrm{N}$ excretion was significantly reduced by addition of threonine, to the greatest extent with $\mathrm{I} \cdot 2 \mathrm{~g} / \mathrm{kg}$, but the results were too variable to define an optimum precisely; there was no evidence of an advantage in adding more than $1 \cdot 2 \mathrm{~g} / \mathrm{kg}$ but this possibility was examined further in the following experiment.

\section{Expt 2}

To identify the third-limiting amino acid the basal diet was supplemented with L-lysine $\left(4^{\circ} \circ \mathrm{g} / \mathrm{kg}\right)$ and $\mathrm{L}$-threonine $(\mathrm{I} \cdot 2 \mathrm{~g} / \mathrm{kg})$. In the second part of the experiment the responses to additions of isoleucine, methionine or tryptophan were measured, as well as to further additions of lysine and threonine. The results, which are given in Table 5, showed that none of these amino acids significantly affected $\mathrm{N}$ excretion.

\section{Expt 3}

To provide further confirmation that the third-limiting amino acid was not isoleucine, methionine or tryptophan, this experiment examined the effect of restoring each to a mixed amino-acid supplement from which it had been deleted. The experiment, which was reported briefly by Fuller et al. (1975) consisted of three periods, each of Io d. In the first period all fifteen pigs were given the basal diet of barley with minerals and vitamins but with no amino acids added. In the second period a mixture of amino acids was added, but for each group of three pigs one of the five amino acids was deleted from the mixture; in the third period the mixture for all pigs was completed by the addition of the missing amino acid. For the last Io $d$ all pigs had the same amino acid mixture, shown in Table $\mathrm{I}$. The daily excretions of urea by all pigs, and of $\mathrm{N}$ by three pigs, were measured. The responses of daily urea excretion are shown in Table 6. Addition of mixtures devoid of methionine, isoleucine or tryptophan reduced daily urea excretion by approximately $\mathrm{Io} g$; restoration of the missing amino acid produced no further change, confirming the finding of Expt 2 that none of these amino acids was third-limiting. The mixture lacking lysine gave no response; that without threonine was intermediate, confirming that these were the first- and second-limiting amino acids. The final rate of urea excretion was on average $3.4 \mathrm{~g} / \mathrm{d}$ (range $\mathrm{I}-6 \mathrm{~g}$ ).

This experiment also provided further confirmation of the rapidity with which $\mathrm{N}$ excretion re-equilibrated after additions of amino acids to the diet. Fig. I shows the time-course of daily urea excretion by pigs given each of the five amino acid mixtures. It is clear that a new equilibrium rate of urea excretion was reached within 2-3 d of adding the amino acids. 
2

ฐัฐ

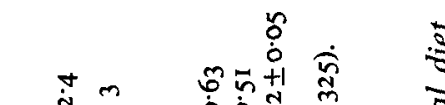

ป

$\frac{2}{8}$

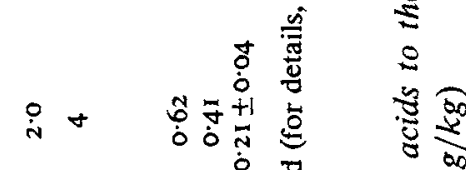

齐

20

$\frac{5}{8}$

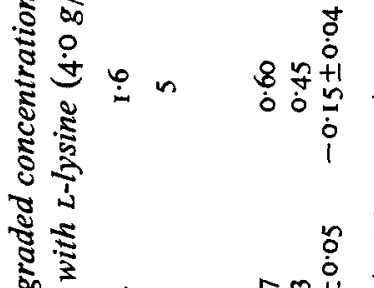

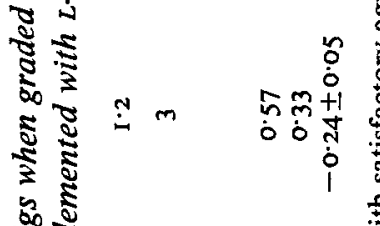

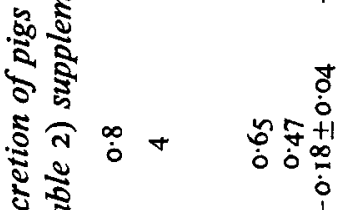

究

ङ

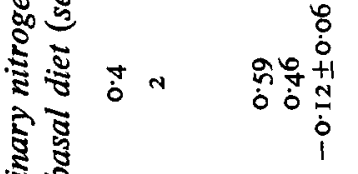

空

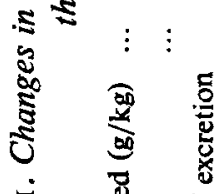

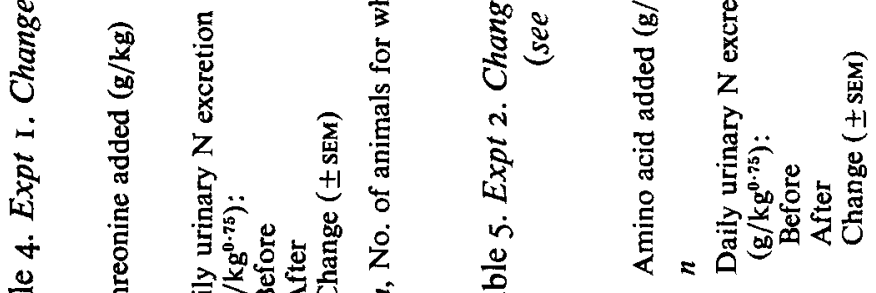

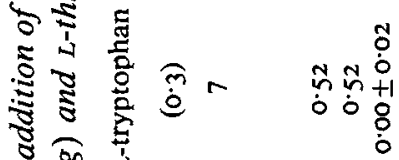

$\underset{\infty}{\frac{\infty}{2}} \frac{\infty}{\infty}$

竎

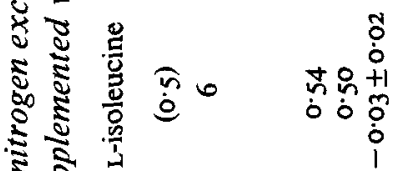

ते

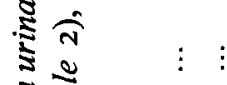

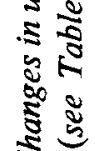

車

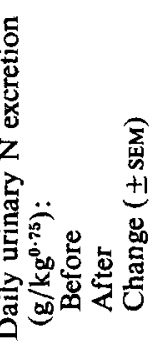

$\$$

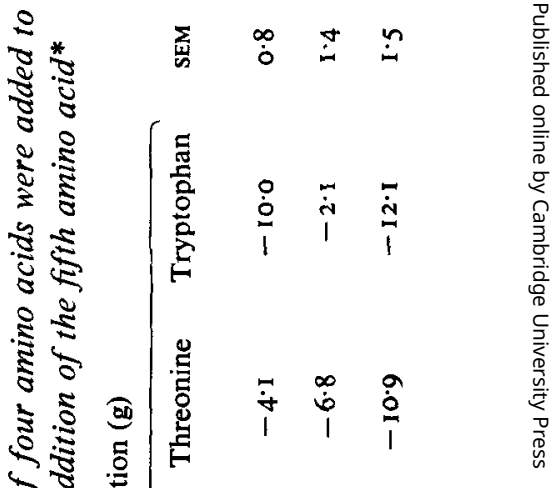

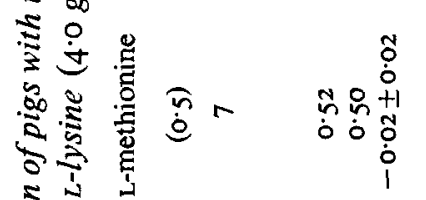

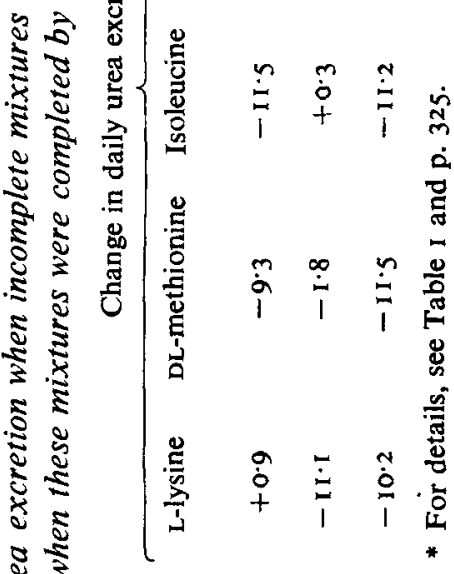

จ

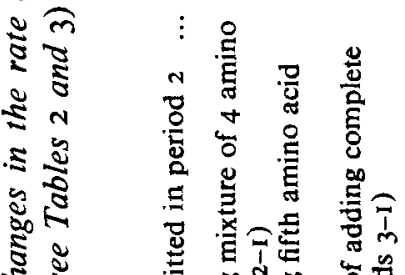

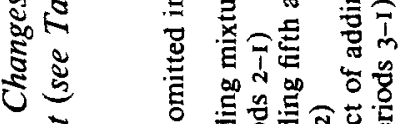

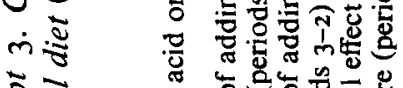

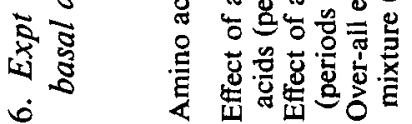

○

$\frac{0}{0}$ 


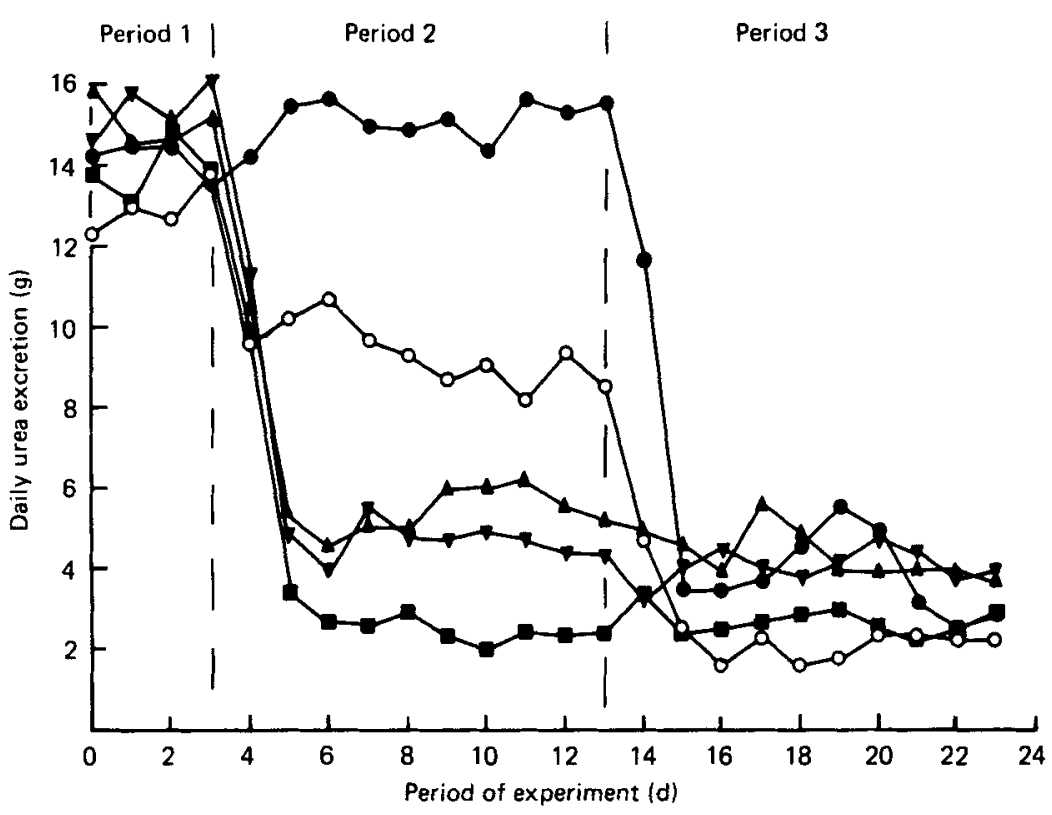

Fig. 1. Expt 3. Daily urea excretion (g) of pigs given a basal diet of barley with vitamins and minerals (period I), which was then supplemented with incomplete mixtures of amino acids (period 2 ; for details of Expt, see Table I): (O), lacking lysine; (O), lacking threonine; ( $\mathbf{m})$, lacking isoleucine; $(\Delta)$, lacking methionine; $(\nabla)$, lacking tryptophan. In period 3 the missing amino acid was added. Each value is the mean of three animals.

Table 7. Expt 4. Changes in urinary nitrogen excretion when single amino acids were added to the basal diet (see Table 2) supplemented with L-lysine $(4 \cdot 0 \mathrm{~g} / \mathrm{kg})$ and L-threonine $(\mathrm{I} \cdot 2 \mathrm{~g} / \mathrm{kg})$

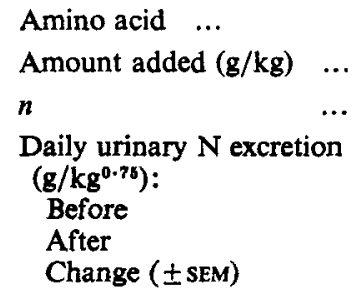

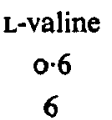

6

0.45
0.47
$+0.01 \pm 0.03$

L-leucine
0.6

5

0.44
0.44
$0.00 \pm 0.04$

L-histidine

0.4

6

0.46
0.40
$-0.06 \pm 0.03$

$n$, No. of animals/treatment.

\section{Expt 4}

Of the other essential amino acids, the phenylalanine + tyrosine in the barley are alone in exceeding any of the estimates of requirements mentioned previously (see p. 322). This experiment therefore examined the responses to leucine and histidine and to valine, which Ivan (1974) showed to be the third-limiting amino acid in wheat. The results, given in Table 7 , showed that leucine and valine were without effect but that addition of histidine produced a moderate decrease in $\mathrm{N}$ excretion. Histidine was therefore tentatively judged to be the thirdlimiting amino acid and the next experiment was designed to confirm this and to determine the optimal level at which it should be added.

\section{Expt 5}

The responses of urine $\mathbf{N}$ to graded additions of histidine are shown in Table 8. There was a significant reduction in $\mathrm{N}$ excretion with the inclusion of histidine, but no indication of an 
Table 8. Expt 5. Changes in urinary nitrogen excretion when graded concentrations of histidine were added to the basal diet (see Table 2) supplemented with L-lysine $(4.0 \mathrm{~g} / \mathrm{kg}$ ) and L-threonine $(\mathrm{I} \cdot 2 \mathrm{~g} / \mathrm{kg})$

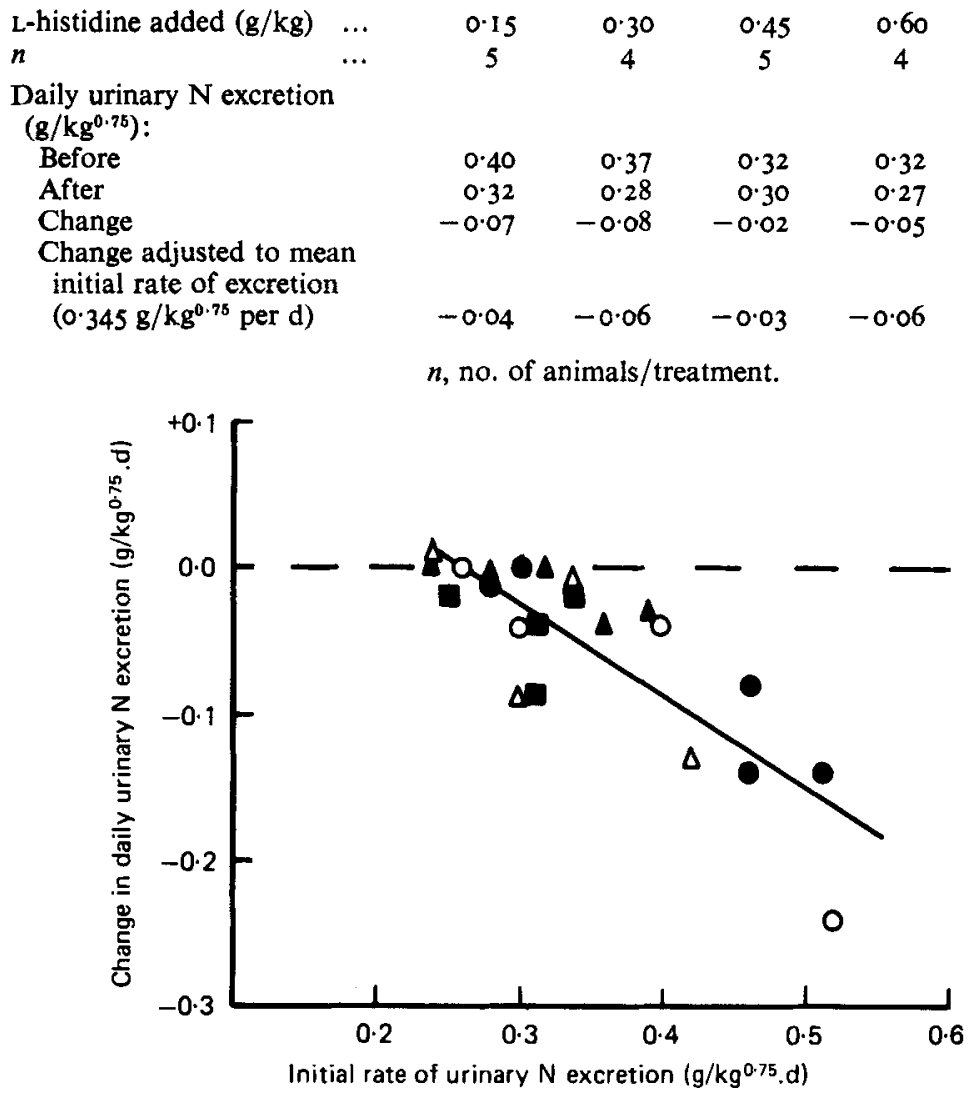

Fig. 2. The relationship between the initial rate of urinary $\mathrm{N}$ excretion $\left(\mathrm{g} / \mathrm{kg}^{0.75}\right.$ per $\left.\mathrm{d}\right)$ and its change $\left(\mathrm{g} / \mathrm{kg}^{0.75}\right.$ per d) when histidine was added to the diet at various rates $(\mathrm{g} / \mathrm{kg}):(0), 0.15$; $(\bigcirc), 0.30 ;(\Delta), 0.45 ;(\Delta), 0.60 ;(\square), 0.75$. For details of Expt, see Table I.

optimum: there was a suggestion that the response was reduced by adding more than $0.3 \mathrm{~g} / \mathrm{kg}$. The mean rate of $\mathrm{N}$ excretion after addition of histidine was $0.29 \mathrm{~g} / \mathrm{kg}^{0.75}$ per d. There was, however, considerable variation in the response of pigs at each level of histidine. The nature of this variation was revealed by examination of the relationships between the rate of $\mathrm{N}$ excretion before addition of histidine and the response of the pig to the addition. These are shown in Fig. 2. Linear regressions relating the change in $\mathrm{N}$ excretion to its previous rate were combinable: the pooled regression coefficient was $-0.63 \pm 0 . \mathrm{I}$. The responses to histidine at a constant initial rate of $\mathrm{N}$ excretion were examined by covariance analysis. This gave no clearer indication of an optimum addition of histidine. From the pooled equation it could be inferred that with an initial rate of $\mathrm{N}$ excretion of $0.26 \mathrm{~g} / \mathrm{kg}^{0.75}$ there would be no response to the addition of histidine.

A re-examination of the responses to threonine in Expt $I$ and to lysine in the experiment reported earlier (Fuller et al. 1974) also showed a tendency for the magnitude of the response to these amino acids to depend upon the previous rate of $\mathrm{N}$ excretion; in these instances, however, the relationships were not as clear, nor were they statistically significant. 
There are several possible explanations for these observations. The first is simply that because of the normal cyclic fluctuations in $\mathrm{N}$ excretion an animal with a high rate of $\mathrm{N}$ excretion in the first period compensated by excreting less in the second. According to this reasoning, Fig. 2 shows this tendency of $\mathrm{N}$ excretion to regress to the mean superimposed on a general reduction in $\mathrm{N}$ excretion after addition of histidine.

The second possible explanation is that the relationship represents the inherent variation amongst pigs in the efficiency with which they utilized the amino acid (in this instance histidine) in their basal diet. Those which utilized it efficiently had low rates of $\mathrm{N}$ excretion in period $\mathrm{I}$ and did not respond to addition of histidine: for these animals histidine was not limiting. Those animals which utilized it less efficiently responded to additions of histidine and for them histidine therefore was the third-limiting amino acid in the barley. Support for this hypothesis comes from an examination of the familial relationships of the pigs. There was a significant tendency $(P<0.05)$ for litter-mates to respond similarly in this respect.

A third explanation is that in dietary histidine deficiency there may be a release of histidine from carnosine, which is abundant in pig muscle (Easter \& Baker, 1977; C. I. Harris, personal communication). A depletion of carnosine in dietary histidine deficiency has been demonstrated in several species (Chung-Kwang et al. 1976; Easter \& Baker, 1977; Quinn \& Fisher, 1977; Robbins et al. 1977). Variation between animals in the extent of carnosine breakdown could give rise to the responses observed.

The general reduction in urinary $\mathrm{N}$ excretion seen in response to histidine supplementation suggests that, for most of the pigs, histidine was the third-limiting amino acid in the barley, and that addition of not more than $0.3 \mathrm{~g} / \mathrm{kg}$ diet was sufficient to remedy its deficiency.

\section{Comparison of urea and total $N$ excretion}

Simultaneous estimates were made of the rates of $\mathrm{N}$ and urea excretion of all pigs in Expts 4 and 5 and of three pigs in Expt 3. There was a close linear relation between them, described by the equation:

$$
N=3.3+0.48 U( \pm 0.034) \text { residual SD I } 2 \text {, }
$$

where $N$ and $U$ are the daily rates of $\mathrm{N}$ and urea excretion respectively. As I $\mathrm{g}$ urea contains $0.467 \mathrm{~g} \mathrm{~N}$ the regression coefficient provides an estimate that $97 \%$ of an increase in $\mathrm{N}$ excretion was accounted for by urea.

\section{General discussion}

The mean rate of urinary $\mathrm{N}$ excretion after the addition of histidine (not less than $0.3 \mathrm{~g} / \mathrm{kg}$ ) was $0.27 \mathrm{~g} / \mathrm{kg}^{0.75}$ per d, and it is relevant to enquire how much further it might be reduced by improvements in amino acid balance. Conventionally, a biological value (BV) of $\mathrm{I} \cdot 0$ is ascribed to a protein, which, when fed as 8 or $10 \%$ of the diet, causes no increase in $\mathrm{N}$ excretion above that found on protein-free diets In our earlier experiments (Fuller \& Crofts I977) pigs of this weight from the same herd, given protein-free diets, had a daily urinary $N$ excretion of $0.15 \mathrm{~g} / \mathrm{kg}^{0.75}$ and a daily faecal $\mathrm{N}$ loss of $0.06 \mathrm{~g} / \mathrm{kg}^{0.75}$. Using these values the $\mathrm{BV}$ of the supplemented barley protein was 0.93 , compared with a value of $0.5 \mathrm{I}$ for the unsupplemented barley (Expt 3, period I).

Other, internal evidence provides a slightly higher estimate of the irreducible minimum urinary $\mathrm{N}$ loss. In an ideally-balanced protein all amino acids are completely utilized, none is catabolized and there is no excretion of urea. From the relationship between $\mathrm{N}$ and urea excretion described previously it would be expected that with complete inhibition of urea excretion there would be a daily $N$ output in the urine of $3.3 \mathrm{~g}$ or $0.23 \mathrm{~g} / \mathrm{kg}^{0.75}$. The composition of this residual $\mathrm{N}$ excretion is not known but it may include metabolites arising from nitrogenous compounds other than amino acids contained in the barley. It may therefore be regarded as a more appropriate estimate of the limit to improvement than the $\mathrm{N}$ excretion on 
Table 9. Estimates of amino acid requirements $(\mathrm{g} / \mathrm{\textrm {I }} 60 \mathrm{~g} N)$ compared with the amino acid composition of the supplemented barley protein and of the whole-body protein of growing pigs

\begin{tabular}{|c|c|c|c|c|c|}
\hline \multirow{3}{*}{ Source $\quad \ldots$} & \multicolumn{3}{|c|}{ Estimate of requirements } & \multirow{3}{*}{$\begin{array}{c}\text { Supple- } \\
\text { mented } \\
\text { barley (pre- } \\
\text { sent experi- } \\
\text { ments) }\end{array}$} & \multirow{3}{*}{$\begin{array}{c}\text { Whole-body } \\
\text { protein of } \\
\text { pigs* }\end{array}$} \\
\hline & \multicolumn{2}{|c|}{$\begin{array}{l}\text { Agricultural Research } \\
\text { Council (1967) }\end{array}$} & \multirow{2}{*}{$\begin{array}{c}\text { National } \\
\text { Research } \\
\text { Council } \\
\text { (1973) }\end{array}$} & & \\
\hline & & $\mathrm{Up}$ to & & & \\
\hline Wt $(\mathrm{kg}) \quad \ldots$ & $9-20$ & $45-50$ & $20-60$ & 35 & $15-40$ \\
\hline Lysine & 58 & 48 & 44 & 73 & 70 \\
\hline Methionine + cystine & 35 & 34 & $3 \mathrm{I}$ & 39 & 30 \\
\hline Tryptophan & 8 & 9 & 8 & 9 & 8 \\
\hline Histidine & I 2 & - & I I & 23 & 25 \\
\hline Phenylalanine + tyrosine & 27 & 一 & $3 I$ & 70 & 63 \\
\hline Threonine & 23 & 29 & 28 & $4 I$ & 37 \\
\hline Leucine & 37 & - & 37 & 61 & 68 \\
\hline Isoleucine & 35 & 39 & $3 I$ & 32 & 35 \\
\hline Valine & 25 & - & $3 I$ & 46 & 47 \\
\hline
\end{tabular}

* From Aumaitre \& Duée (1974) and Shmanenkov \& Burin (1971).

a protein-free diet. If this is so, the BV of the supplemented barley protein would be estimated to be 0.97 .

Since the supplemented barley had a BV approaching $\mathrm{I} \cdot 0$ it can be regarded as a first approximation in these studies of an ideally balanced protein. As such, it is instructive to compare its amino acid balance with those recommended by the Agricultural Research Council (1967) and (US) National Research Council (1973). These comparisons are made in Table 9. The supplemented protein contains much higher proportions of lysine, phenylalanine + tyrosine, histidine, leucine and valine than either the Agricultural Research Council (1967) or National Research Council (1973) consider to be required. By contrast, the amino acid composition of the supplemented barley shows a close similarity to that of the wholebody proteins of pigs. This is also shown in Table 9, where it may be seen that the only notable discrepancies are in the higher contents of phenylalanine + tyrosine and of methionine + cystine in the barley. As mentioned on p. 227, the phenylalanine + tyrosine in barley are alone in exceeding current estimates of requirements expressed as a percentage of the diet: it may therefore be that reduction in the amounts of these amino acids in the barley, were it possible, would improve the BV of its protein. The same may also be true of the sulphur amino acids, though in this instance the continuous loss of hair and skin debris rich in cystine may mean that the optimal concentrations of $S$ amino acids in dietary protein exceed those found in body protein.

The concept that an animal's requirements for amino acids, both in quantity and in proportions, depend ultimately on the amount and composition of the body protein formed, has a long history. It was advanced explicitly by Mitchell (1950) who noted particularly the peculiar amino acid composition of the keratins, the synthesis of which dominates maintenance protein requirements, requiring large amounts of the $S$ amino acids and little lysine, histidine or phenylalanine, compared with the proteins of muscle, blood and viscera. In the instance of the growing pig requirements for the formation of new tissue, rather than for maintenance, predominate, and in such instances the theory would predict that a protein with a high BV would resemble in its amino acid composition the tissues of the animal to which it is fed. The theory implies that all amino acids in an ideally balanced protein are 
used with equal efficiency, i.e. $100 \%$, though only at protein intakes at which Bv is maximal; this does not necessarily mean that efficiencies remain equal at higher protein intakes.

The authors acknowledge with gratitude the generous gift of amino acids by Ajinomoto Co. Inc., Tokyo, Japan, and wish to thank Mr A. R. Pirie for the amino acid analyses and $\mathrm{Mr}$ A. W. Boyne for the statistical analysis.

\section{REFERENCES}

Agricultural Research Council (1967). The Nutrient Requirements of Farm Livestock No. 3, Pigs. London: Agricultural Research Council.

Aumaitre, A. \& Duée, P. H. (1974). Annls Zootech. 23, 231.

Aw-Yong, L. M. \& Beames, R. M. (1975). Can. J. Anim. Sci. 55, 765.

Chung, A. S. \& Beames, R. M. (1974). Can. J. Anim. Sci. 54, 429.

Chung-Kwang, E., Khurana, H. \& Fisher, H. (1976). J. Neurochem. 26, 1087.

Easter, R. A. \& Baker, D. H. (1977). J. Nutr. 107, I 20.

Fuller, M. F. \& Crofts, R. M. J. (1977). Br. J. Nutr. 38, 479.

Fuller, M. F., Livingstone, R. M. \& Mennie, I. (1974). Proc. Nutr. Soc. 33, 91 A.

Fuller, M. F., Livingstone, R. M. \& Mennie, 1. (1975). Proc. Nutr. Soc. 34, 99 A.

Fuller, M. F., Mennie, I. \& Crofts, R. M. J. (1979). Br. J. Nutr. 4I, 333.

Ivan, M. (1974). A nutritional evaluation of wheat for pigs with a particular reference to quality and quantity of protein. PhD Thesis, University of New England.

Marsh, W. H., Fingerhut, B. \& Miller, H. (I965). Clin. Chem. rr, 624.

Matheson, N. A. (1973). Proc. Nutr. Soc. 32, 99 A.

Mitchell, H. H. (1950). In Protein and Amino Acid Requirements of Mammals, p. I [A. A. Albanese, editor]. New York: Academic Press.

National Research Council (1973). Nutrient Requirements of Domestic Animals No. 2, Nutrient requirements of Swine. Washington, DC: National Academy of Sciences.

Quinn, M. R. \& Fisher, H. (1977). J. Nutr. ro7, 2044.

Rérat, A. \& Lougnon, J. (1968). Wld Rev. Anim. Prod. 4, 66.

Robbins, K. R., Baker, D. H. \& Norton, H. W. (1977). J. Nutr. 107, 2055.

Rosenberg, H. R. (1959). In Protein and Amino Acid Nutrition, p. 383 [A. A. Albanese, editor]. London: Academic Press.

Rosenberg, H. R. \& Eckert, R.E. (1961). Progress in Meeting Protein Needs of Infants and Pre-school Children, p. 45I. Publ. no. 843. Washington, DC: National Academy of Sciences.

Shmanenkov, N. A. \& Burin, V. (197I). Fiziologo-biokhimicheskie osnovy povysheniya produktivnosti sel'skokhozyaistvennykh zhivotnykh, p. 5. Moscow, USSR: Izdatel'stvo Kolos. 